\title{
O TRÁGICO EM FIGURAÇA
}

Diogo Liberano é diretor teatral e dramaturgo, e doutorando em Literatura, Cultura e Contemporaneidade pela PUC-Rio. Atualmente, é professor da Faculdade CAL de Artes Cênicas, coordenador do Núcleo de Dramaturgia SESI Rio de Janeiro e diretor artístico e de produção da companhia carioca Teatro Inominável. E-mail: diogoliberano@gmail.com

\section{Resumo}

O ensaio apresenta reflexões sobre a dimensão do trágico na contemporaneidade a partir da performance FIGURAÇA da artista brasileira Flávia Naves. O texto aborda questões do corpo e do feminino e, sobretudo, como a performer, por meio de sua prática, se relaciona e problematiza - social e artisticamente - a sua condição de mulher. Para isso, se apoia em conceitos como o de "multidão" (NEGRI) e "profanação" (AGAMBEN) para compor suas reflexões.

\section{Palavras-chave}

Performance. Feminino. Trágico. Multidão. Profanação.

Duas décadas atrás, a revista semanal esquerdista alemã Stern fez uma experiência

muito cruel: pagou a um homem e a uma mulher sem-teto paupérrimos para que tomassem banho, e ao homem para que se barbeasse minuciosamente, e depois os entregou aos melhores estilistas e cabelereiros. Em seguida, numa de suas edições, a revista publicou duas fotos de página inteira dessas pessoas, lado a lado, primeiro em sua condição miserável de semteto, ambos sujos e o homem com a barba por fazer, e depois vestidos por um grande estilista. $O$ resultado foi eficazmente insólito: embora ficasse claro que estávamos lidando com as mesmas pessoas, o efeito da roupa diferente etc. foi de que uma de nossas crenças - a que diz que por trás da aparência diferente está uma e a mesma pessoa - ficou abalada. Não era apenas a aparência que estava diferente: $o$ efeito profundamente perturbador dessa mudança de aparência foi que nós, os espectadores, de algum modo percebemos uma personalidade diferente sob ela. A Stern foi bombardeada com cartas dos leitores, que acusaram a revista de violar a dignidade dos sem-teto, de humilhá-los, submetê-los a uma piada cruel (...). Em suma, de certo modo, esse experimento demonstrou empiricamente que (...) o núcleo da nossa subjetividade é um vazio preenchido por aparências.

Slavoj Zizek (2006, p. 110). 


\section{1) Histórico}

O presente artigo busca compor e apresentar reflexões sobre a dimensão do trágico na contemporaneidade a partir do trabalho da artista brasileira Flávia Naves. Para abordar questões relativas ao trágico, lança o olhar sobre o corpo e o feminino na pós-modernidade. Nesta primeira seção, apresenta-se um breve apanhado histórico visando marcar as distintas investidas da disciplina e do controle dos corpos em sociedades disciplinares (Michel Foucault) e de controle (Gilles Deleuze).

Em reflexões que datam de 1975 e analisam a relação entre o poder e o corpo no século XVIII, Michel Foucault ressalta que a consciência do corpo só pôde ser adquirida a partir do investimento que o poder fez sobre os corpos. Este poder sobre o corpo se manifesta por aspectos diversos, tais como pela ginástica, pelos exercícios, pelo desenvolvimento muscular, bem como pela exaltação do corpo belo e pela nudez. Foucault, no entanto, pondera que ao agir sobre corpos, inevitavelmente, o poder fez também emergir reinvindicações de tais corpos contra o poder investido sobre eles. $\mathrm{O}$ autor afirma: "a saúde contra a economia, o prazer contra as normas morais da sexualidade, do casamento, do pudor. E, assim, o que tornava forte o poder passa a ser aquilo por que ele é atacado..." (FOUCAULT, 1979, p. 146).

Em Vigiar e punir, ao discorrer sobre a escrita espacial do exercício das disciplinas, Foucault chama atenção para aquela que julga ser a primeira das grandes operações da disciplina, que seria justamente a constituição de "quadros vivos", ou seja, o enquadramento, a contenção e a organização da multiplicidade humana. Ele afirma que no século XVIII, o quadro "é ao mesmo tempo uma técnica do poder e um processo de saber. Trata-se de organizar o múltiplo, de se obter um instrumento para percorrê-lo e dominá-lo; trata-se de lhe impor uma 'ordem"” (FOUCAULT, 2014, p. 145).

Em Por uma genealogia do poder, introdução de Roberto Machado para Microfísica do poder de Foucault, Machado contextualiza historicamente o século XVIII, a partir de aspectos como a explosão demográfica e o crescimento do aparelho de produção, ressaltando que a dominação política do corpo se manifesta como maneira de fazer uso dos corpos em sociedade visando aproveitamento econômico. Machado sugere que: "a grande importância estratégica que as relações de poder disciplinares desempenham nas sociedades modernas depois do século XIX vem justamente do fato de elas não serem negativas" (FOUCAULT, 1979, p. xix). Ele afirma: 
A ação sobre o corpo, o adestramento do gesto, a regulação do comportamento, a normalização do prazer, a interpretação do discurso, com o objetivo de separar, comparar, distribuir, avaliar, hierarquizar, tudo isso faz com que apareça pela primeira vez na história esta figura singular, individualizada - o homem - como produção do poder. Mas também, e ao mesmo tempo, como objeto do saber. (FOUCAULT, 1979, p.xx)

É importante reconhecer, a partir das reflexões de Machado, que o poder é produtor de individualidade e que o indivíduo, assim, é também uma produção do poder e do saber. Porém, tais afirmações só podem ser compreendidas se retirarmos delas qualquer juízo de valor moral ou político. Estamos falando da tecnologia empregada pelo homem para entender o homem em relação social, pois as técnicas disciplinares são também técnicas de individualização, um tipo específico de saber fruto das ciências humanas tão em voga a partir do século XVIII.

É o historiador Stephen Kern, em sua obra The culture of time and space, 1880 1918, que reconhece como a Primeira Guerra Mundial só foi possível por conta de avanços inúmeros dos sistemas de transporte e comunicação. Ele pontua que uma das grandes ironias do período foi justamente o fato de a guerra só ter sido possível após o mundo ter conseguido estar mais unido. A gravidade dessa discussão, já prevista por Foucault em suas leituras sobre o projeto disciplinar, diz respeito ao uso que a economia do capital fez e ainda faz dos saberes descobertos pelas ciências humanas.

Em seu Post-scriptum sobre as sociedades de controle, publicado em 1990, Gilles Deleuze afirma que o próprio Foucault sabia que a sua noção de sociedade disciplinar surgia como sucessão às sociedades de soberania, cabendo a Deleuze reconhecer que, após a Segunda Guerra, migramos de uma sociedade disciplinar para uma sociedade de controle. Deleuze sugere que o dinheiro talvez seja o parâmetro que "melhor exprima a distinção entre as duas sociedades, visto que a disciplina sempre se referiu a moedas cunhadas em ouro - que servia de medida padrão -, ao passo que o controle remete a trocas flutuantes" (DELEUZE, 1992, p. 226).

Deleuze se interessa em ler uma determinada sociedade a partir de certos tipos de máquinas que tais sociedades movimentam e, sobretudo, criam. Analisando a mutação das máquinas em sociedade, o filósofo observa que não se trata meramente de uma evolução tecnológica de tais máquinas, mas essencialmente de uma mutação do capitalismo. Contrapondo o capitalismo do século XIX ao do XX, reconhece que de 
uma produção interessada em concentração e em propriedade se chegou a um capitalismo de superprodução, assentado na venda de serviços e na compra de ações. Isso configurou outro corpo social, mais dispersivo, pois a fábrica - característica das sociedades disciplinares - cedeu lugar à empresa. E a perversão de nossa época é justamente o fato de que a empresa abandonou os espaços fechados para ocupar os circuitos abertos do banco, da troca monetária tornada virtual. Deleuze assegura:

O marketing é agora o instrumento de controle social, e forma a raça impudente dos nossos senhores. O controle é de curto prazo e de rotação rápida, mas também contínuo e ilimitado, ao passo que a disciplina era de longa duração, infinita e descontínua. O homem não é mais o homem confinado, mas o homem endividado. (DELEUZE, 1992, p. 228)

Pois se as operações do marketing possibilitam a manutenção e a multiplicação de novas e diversas empresas, elas também rendem o homem de um modo ainda mais impiedoso ao confrontá-lo com imagens sem carne e humanidades bidimensionais tratadas a Photoshop. Se o homem contemporâneo se vê refletido em imagens que não cessam de atualizar seus valores e aparências, de impor-lhe gostos, há que se perguntar o que resta ao corpo humano. Pois se o corpo era o recipiente da personalidade humana, o que resta agora que o corpo já não mais é dado como sinônimo da inteireza humana? O que resta ao homem se o corpo foi tornado apenas casca que se pode facilmente adulterar, corpo-imagem de curta duração, perene, solto à voracidade da publicidade?

Em seu artigo $O$ eu é o corpo, a psicanalista Maria Rita Kehl reconhece que “dizemos sempre 'meu corpo', como se existisse um eu em algum lugar externo ao corpo que é dono desse corpo". E, em seguida, ela sentencia que "não existe nenhum eu em nenhum outro lugar que não seja o próprio corpo. Quer dizer, o eu é o corpo" (KEHL, 2005, p. 110). No entanto, se retomarmos à epígrafe de Slavoj Zizek, será mesmo que o núcleo da subjetividade humana passou a ser um vazio preenchido por aparências que não param de se modificar? Mais que isso: a quem pode interessar que a condição humana tenha se tornado este projeto tão desprovido de raiz, tão sem fundamento, tão sem corpo? 


\section{2) Lógica}

O que resta ao homem se o corpo foi tornado apenas casca que se pode facilmente adulterar? O que resta à mulher? Seria possível escapar a essa lógica perversa investida pelo capital? Seria possível denuncia-la e propor alternativas ao corpo feminino? A performer francesa Mireille Suzanne, ao adotar o nome ORLAN (escrito em letras garrafais) em 1971, sugere um caminho. Ela passa a realizar uma série de performances que agem de forma incisiva sobre o seu próprio corpo. No trabalho mais comentado de sua trajetória, em 1990, apresenta A Reencarnação de Santa ORLAN, realizando uma série de cirurgias plásticas e transformando a si mesma a partir de pinturas e esculturas famosas que representam o corpo feminino.

O que me parece determinante ao citar o trabalho de ORLAN é justamente o fato de se tratar de operações performáticas sobre o seu próprio corpo, modificando aquilo que nos acostumamos a ter como condição natural de um indivíduo. ORLAN muda o rosto e a própria identidade. Mais que isso: por meio de cirurgias plásticas, ela realiza ações sem possibilidade de retorno e, paralelamente a tais experiências, ainda produz um vasto discurso teórico explicando e fundamentando suas escolhas.

Analisando o trabalho dessa performer, Josette Féral chama atenção para o seu discurso social, interessado em revelar "preocupações que atingem a imagem da mulher na arte e na sociedade assim como na prática da cirurgia plástica e no sentido que essa última ocupa nas nossas estruturas mentais" (FÉRAL, 2015, p. 207). Mais do que um feminismo, ORLAN desmantela seu próprio corpo para revelar o corpo como obsoleto, sempre incapaz de lidar com a situação humana porque ser humano é estar sempre em mutação. Féral pontua:

O que Orlan marca assim sobre seu corpo é seu desejo da diferença, da alteridade, sua recusa em aderir a uma identidade definida de uma vez por todas. Ela revela desse modo o avesso de sua pessoa, o universo de suas fantasias - artísticas e outras - invertendo a ordem das coisas, fazendo vir à tona, de modo visível para o observador, aquilo que normalmente permanece oculto no indivíduo. (FÉRAL, 2015, p.211)

Há, pois, um desejo de multidão. De ser múltiplo. De não ter contorno justamente porque o contorno é caixa e a diferença é fluxo, corredeira, não pode caber, não vai caber. Desprovido de contornos precisos, desorganizado pela emergência dos 
hibridismos e pelo borrar das fronteiras, globalizado, o homem pós-queda do Muro de Berlim não encontra mais no corpo o suporte decisivo de sua humanidade. Onde, então, mora o humano que não mais - e apenas - em um corpo?

\begin{abstract}
Hoje, valorizado, cultivado, motivado, transformado em objeto do olhar, o corpo sadio tornou-se o objeto de um novo culto social quase universal nas nossas sociedades ocidentalizadas. Os efeitos desse novo culto não são totalmente libertadores porque, nessa operação de revalorização do corpo, este último parece ter perdido toda forma de espiritualidade, transformado em matéria facilmente manipulável, realidade sem profundidade, exibindo-se inteiramente ao olhar, transformado em simples objeto. (FÉRAL, 2015, p. 214)
\end{abstract}

Uma hipótese talvez seja pensar corpo mais como matéria do que como suporte único do que é ser humano. Ao invés de carne, pensar corpo em seu desfazimento, como materialidade, misturando o indivíduo e suas imagens, corpo feito uma maquinaria sem individualidade nem personalidade previamente definidas. Pois se a inteireza do corpo se fragiliza, também estamos falando de um corpo incapaz de ser organizado e desinteressado no imperativo das empresas e organizações que legislam seu desejo; estamos falando de um corpo-resposta à doença do capital: corpo pleno sem órgãos que é justamente "o improdutivo, o estéril, o inengendrado, o inconsumível” (DELEUZE, G. e GUATTARI, F., 2004, p. 13). Um corpo que "não é o testemunho de um nada original, nem o resto de uma totalidade perdida. [...] não tem nada a ver com o corpo de cada um nem com uma imagem do corpo. É o corpo sem imagem" (Ibidem, p. 14).

Partindo dessa analogia à noção de corpo sem órgãos $(\mathrm{CsO})$ desdobrada por Félix Guattari e Gilles Deleuze - e reconhecendo que a prática-corpo de ORLAN é exercício que visa desorganizar o adestramento do corpo humano em uma sociedade rendida pelo capital - busca-se também especular sobre como a criação artística está implicada no desfazimento das normatizações sobre o corpo e da moralização de seus afetos e desejos. Pois se o $\mathrm{CsO}$ é produção nascida dentro da dinâmica produtiva do desejo, é também um produto que se manifesta improdutivo. Logo, mesmo sendo produzido, não pode bem ser consumido, mas ainda assim se produz. E se está desinteressado em resgatar um ponto de origem e em se fechar, atingir alguma totalidade, logo é também corpo desinteressado em autoria e autoridade, corpo antifascista. É corpo mesmo sem ter corpo porque sequer se apresenta como espaço portador de imagens, não porque as ignore, mas sim porque não cai de amor por elas. As imagens não têm valor de eternidade porque não existem como suprimento à falta 
que é estar vivo. Um corpo sem imagens é então um corpo disposto a toda e qualquer imagem, porém, numa lógica de atravessamento e cruzamento, não de confinamento nem de tatuagem.

Pois se há um desejo de multidão, uma sede por alteridade, é curioso constatar que também a arte saiu dos espaços destinados à sua exibição - saiu de seu corpo instituído - para flertar com a rua. A malha urbana, para muitos artistas, virou sua indumentária. Há inúmeros processos artísticos contemporâneos que fazem sua escrita por meio de derivas etnográficas, numa busca não mais pelo o que já se sabe nem pelo que se deseja apenas, mas, sobretudo, por aquilo que ainda não veio, pelo que não se sabe, em busca do outro que não eu.

Pensar um desejo de multidão é pensar em singularidade, potência e imanência. É também olhar detidamente à alegria dos afetos. A partir de Antonio Negri, em parceria com Michael Hardt, pode-se ler a noção de multidão como um conjunto de singularidades que produz além da medida. Que medida? Imagino que ela diga respeito à medida do instituído, do autorizado e permitido; medida imposta aos homens e às mulheres pela vida capitalística. Se multidão é um conjunto de singularidades que produz além da medida, ora, qual é então a relação do poder com a multidão?

\footnotetext{
Não há certamente nada que o poder possa fazer com ela, porque aqui as categorias que interessam ao poder, isto é, a unidade do sujeito (povo), a forma de sua composição (contrato entre os indivíduos) e a forma de governo (monarquia, aristocracia e democracia, separadas ou combinadas) sempre foram deixadas de lado. (NEGRI, 2003, p. 166167)
}

Pois se a multidão é prática que opera sem estar rendida pelo poder, mas justamente em tensão com o poder instituído, pensar em termos de singularidade, potência e imanência (características da multidão) é pensar por meio de movimentos outros capazes de descodificar esse meio instituído. E o meio instituído é justamente essa acumulação e sedimentação de hábitos, valores e morais que informam quais corpos são ou não permitidos em sociedade; diz respeito à produção de estratos de acordo com Deleuze e Guattari. “A estratificação é como a criação do mundo a partir do caos, uma criação contínua, renovada, e os estratos constituem o Juízo de Deus" (DELEUZE, G. e GUATTARI, F., 2012, p. 230-231). Derrotar o Juízo de Deus é forjar processos de subjetividade sob o capitalismo global; é abrir espaço justo onde se busca 
anular a subjetividade, justo onde dispositivos agem visando encarcerar o múltiplo na unidade-travão "povo".

Muito me interessa investigar como algumas práticas artísticas contemporâneas nascidas dentro do estrato capitalista conseguem, ainda assim, ter potência de ação para, em tensão e ultrapassagem dos limites impostos, oferecer respostas à perturbadora questão anunciada por Peter Pál Pelbart: "como é que aqueles que detêm o poder fazem questão de nos afetar de tristeza? As paixões tristes como necessárias ao exercício do poder." (PELBART, 2008, p. 33).

\section{3) Programa}

1) Deambulações pela cidade do Rio de Janeiro: saia de casa com uma máquina fotográfica portátil (pode ser um celular que capture fotos). Percorra calçadas e ruas da cidade do Rio de Janeiro, cruze avenidas e, nessas trajetórias, sempre que passar por alguma pessoa cujo algum traço do corpo lhe chame à atenção (seja por uma atração ou por uma repulsa), dê um jeito de - sorrateiramente - fotografá-la; 2) Captura de imagens de figuras do cotidiano urbano: fotografe sem critério algum, exceto este: ter sua atenção tragada por tal corpo, por tal aparência, por tal figura. Fotografe uma tatuagem, adereços e acessórios, anéis, cordões, joias, bonés, chapéus, gravatas, cintos, brincos, a cor de um batom, o tom de um esmalte. Fotografe como quem disseca uma composição una para ver de quais partes ela é feita. Talvez lhe chame atenção um par de sapatos, talvez uma calça, um colete, um avental. Não é bem sobre a pessoa que mora dentro desse corpo, não é sobre um sujeito, é mero exercício sobre aparência, sobre a imagem. É importante que este jogo de captura não ambicione chegada alguma que não apenas a de fotografar. O que foi capturado virou imagem virtual, fotografia sequer impressa, virou pixel, virou criptografia, números que em arranjos complexos viram ante nossos olhos - imagens na tela de um computador. Retratos do mundo. Fotografe mais, fotografe tudo. Você perceberá que em suas fotografias se poderá também flagrar o chão das ruas, as pedras das calçadas, o calor de um dia ensolarado, a escuridão de uma rua mal iluminada; você há de fotografar, ainda que não queira, também o tremor da sua secreta busca. Eis um programa que culminará numa multidão de imagens que se assemelham entre si apenas porque retratam o ser humano, sempre marcado por tantas e tantas diferenças; 3) Composição - contaminações/apropriações: chegue em casa, passe as fotos da câmera ou celular para um computador. Abra um software capaz de editar 
imagens e comece a recortar das fotos capturadas algumas partes. Um detalhe de um braço fotografado, um pedaço de alguma vestimenta, vá recortando as partes que te seduziram a atenção e componha, sem pretensão de chegada, um novo corpo, quer dizer, uma nova casca, imagem de um possível corpo, posto que ele ainda não exista. Misture os cortes de cabelo com os brincos, os bonés, as saias, as cores distintas. Monte um projeto, uma figura, um ser humano de fina espessura, cujo peso é medido não em quilogramas, mas em bytes. Esta é a fase do programa em que você pode se permitir intencionar, você pode escolher, você pode compor, moldar. Talvez você ache uniforme demais juntar a calça de um senhor fotografado com os tênis de um skatista sarado. Talvez você prefira - já que o jogo te possibilita o impossível - mesclar os códigos culturais. Cabelo feminino com acessórios masculinos, tatuagem de uma adolescente com gravata de um empresário rico. Nesse jogo de composição não importa que o saldo final seja algo reconhecível. É justamente para estranhar a si mesmo e ao mundo que esse jogo se destina. Salve essa fotomontagem. Dê um número a ela. Agora, ela tem por nome "FIGURAÇA número tal". Será a primeira de mais outras que virão. E então o jogo começa - ele sempre está começando - ainda que já tenha começado; 4) Montagem da FIGURAÇA: agora você vai às ruas, não mais para capturar fotos, mas sim para produzir os acessórios, comprar as roupas tal como elas aparecem em sua montagem. Você precisa montar a montagem, precisará fazer aquela tatuagem, tentando atingir o máximo de semelhança da foto capturada. Você precisará cortar o cabelo, pintá-lo, precisará colocar um piercing caso sua fotomontagem lhe diga que isso é necessário; e 5) Saída da FIGURAÇA - convívio social: e assim, montado, travestido, figurado, você viverá um mês de sua vida tal como a foto elaborada por ti. Você viverá a sua vida normalmente, mas com outra aparência, vestido de outra forma.

\section{4) Consistência}

A seção anterior apresenta uma apropriação direta que faço do programa de FIGURAÇA - travestimentos do urbano, da performer goiana - radicada no Rio de Janeiro - Flávia Naves. Durante um ano, ela agiu este programa, compondo e vivendo seis FIGURAÇAS. Considero este trabalho não apenas uma resposta aos ditames de uma cultura que impõe ao corpo e à subjetividade da mulher padrões e morais, mas, sobretudo, uma pergunta-afirmativa que desfaz os moldes de seu corpo feminino para libertar sua subjetividade. Tal como em performances de ORLAN, Naves e sua 
FIGURAÇA escolhem o corpo como espaço primordial para ação e prática de si e do outro. Seu corpo é espaço para a heterogeneidade de singularidades capturadas em deriva urbana, corpo como espaço de montagem e de exibição das figuras montadas, e, sobretudo, corpo-espaço pelo qual se passa o fluxo urbano, corpo-esponja e jamais ponto final de uma final chegada.

Há algum teor trágico, alguma consistência do trágico em FIGURAÇA. Sublinho as implicações levantadas por Carmem Gadelha em $O$ trágico $e$ a contemporaneidade:

\begin{abstract}
A multidão abriga a multiplicidade - não pluralidade numérica, mas potência da diferença; não é apanhada pela metonímia "povo", não tem à frente o proletariado. Ela é força disruptiva, no fim da "sociedade disciplinar" (FOUCAULT). Na "sociedade de controle" (DELEUZE), tecnologias de vigilância in(en)formam o sujeito. Desmaterializada a obra de arte, o fruidor é operador de programas. A arte da presença é abalada: como conceber tragicidade que não incida sobre os corpos? Solapada a inteireza do corpo (falta de carne das imagens, hibridismos), como conceber o humano? É trágica a dor da carne performática? (GADELHA, 2011, p. 4)
\end{abstract}

Arrisco dizer que sim. Obviamente, é preciso fazer distinção entre a poética trágica - a tragédia grega, esmiuçada por Aristóteles em sua Poética - e o trágico não feito um gênero poético, mas como certa relação dialética entre o absoluto e o individual, entre o divino e as suas manifestações e efeitos no corpo social, entre o universal e o particular. É Peter Szondi, em seu Ensaio sobre o trágico, que vai reconhecer ser Walter Benjamin quem consegue aliar, nas reflexões da Origem do drama barroco alemão, a gênese do trágico à gênese da dialética. Se quisermos entender o trágico como uma modalidade dialética, então se faz preciso retomar a prática do corpo sem órgãos dentro das tramas da estratificação capitalista, pois "fora dos estratos ou sem os estratos, já não temos formas nem substâncias, nem organização nem desenvolvimento, nem conteúdo nem expressão" (DELEUZE, G. e GUATTARI, F., 2012, p. 231). O trágico se manifesta, pois, nesse paradoxo que nunca chega, uma vez que esteja rendido pelo diálogo, pela dialética que considera as partes, os vetores em jogo, os afetos. E, se voltarmos a Benjamin, em seu precioso ensaio de 1921, $O$ capitalismo como religião, então veremos que “o capitalismo está essencialmente a serviço da resolução das mesmas preocupações, aflições e inquietações a que outrora as assim chamadas religiões quiseram oferecer resposta" (BENJAMIN, 2013, p. 21). 
Intuo o trágico em FIGURAÇA porque assumo o capitalismo como religião. Ao realizar tal afirmação, faz-se necessário então capturar novamente - em comparação à tragédia ática - as tensões entre o ser humano e os deuses, entre o homem da pólis e a religião mítica. Parece-me que um aspecto da tragédia grega sobrevive na contemporaneidade e ele diz respeito, essencialmente, à desmedida humana. Eis então um enquadramento trágico: a tragédia só se realiza quando o métron é ultrapassado. "No fundo, a tragédia grega, como encenação religiosa, é o suplício do leito de Procrusto contra todas as démesures" (BRANDÃO, 1985, p. 12). De acordo com a mitologia grega, a simbologia de Procrusto faz alusão à intolerância do homem em relação ao seu próprio semelhante. O suplício do leito de Procrusto talvez, então, diga respeito à recusa humana ao limite que lhe é imposto pela aparência de seu corpo (eis um prenúncio de corpo que se volta contra a organização que lhe faz o organismo). Portanto, se a tragédia manifesta a angústia de Procrusto em relação às medidas impostas a ele, "eis aí porque o Estado se apoderou da tragédia e fê-la um apêndice da religião política da pólis” (BRANDÃO, 1985, p. 12).

Se a desmedida humana, na tragédia grega, era uma tensão entre o homem e a religião política de uma pólis em formação, podemos projetar - a partir de Benjamin que se há uma desmedida humana na contemporaneidade ela diz respeito ao duelo do homem com a conformação que lhe é imposta pelo deus de nossa época, o Capital. Nesse sentido, acredito que o trágico se manifesta em FIGURAÇA justamente porque a performer, junto e através de sua prática performativa, tensiona, atravessa e joga com os ditames da cultura capitalista, não interessada em destruí-los, mas, sim, em desorganizálos, em zombar daquilo que a escraviza e dogmatiza, a saber: a condição da mulher enquanto figura social pré-determinada. Sobretudo, acredito no seguinte: a prática de se vestir do outro, de se travestir dos seres da cosmo-pólis Rio de Janeiro, de se figurar - e, nisso, de se desfigurar - é exercício que não prevê chegada que não a do acontecimento, que não apenas a da experiência. Eis um plano - um projeto - de composição porque "reúne concretamente os heterogêneos, os disparates enquanto tais: garante a consolidação dos conjuntos vagos, isto é, das multiplicidades (...) a consistência age no meio, pelo meio, e se opõe a todo plano de princípio ou de finalidade" (DELEUZE, G. e GUATTARI, F., 2012, p. 236). Não se trata de se vestir do urbano, do outro, das múltiplas alteridades, como quem quer se tornar aquilo que não é, mas como quem se dispõe a ser atravessado, desfigurado, como quem se destina a ter a pele marcada, o íntimo mexido, como quem se permite experimentar o que lhe foi proibido por ser ela 
uma mulher, tal como a performer Flávia Naves é (ou era): um longo vestido azul feminino coexistindo durante um mês ao corpo dela que calça um sapato social masculino comprado em loja de produtos só masculinos.

Eis o trágico em FIGURAÇA: jogo sem ponto de origem e sem ponto de chegada. Paradoxo ambulante: identidade, corpo e subjetividade tornados provisórios. Não se trata de assassinar a forma que nos enforma, mas de jogar com ela, fazer novos usos dela, profana-la tal como propõe Giorgio Agamben, encontrar na experiência artística - e por meio dela - um puro meio, ou seja, uma prática que "se emancipou da sua relação com uma finalidade, esqueceu alegremente seu objetivo, podendo agora exibir-se como tal, como meio sem fim." Assim, sentencia Agamben: "a criação de um novo uso só é possível ao homem se ele desativar o velho uso, tornando-o inoperante" (AGAMBEN, 2007, p. 74-75) e, insisto eu, zombando do instituído.

Em FIGURAÇA, um corpo se desfaz em multiplicidade e, ao se travestir desta potência da diferença, afronta as morais vigentes em sociedade passando por elas, como quem passa em fluxo pelo poder sem pretensão alguma de toma-lo. Ora, trata-se então de uma prática cuja finalidade é justamente não se permitir ser útil aos estratos do capital. Livrar-se de ter que ser útil, livrar-se do enquadramento das categorias ditas possíveis, é devolver o corpo e a subjetividade ao jogo dos possíveis, jogo dos plurais, pois nunca se está pronto realmente, nunca se é por completo. Por esse ponto de vista, a performance de Naves se revela a mim também como um gesto de não tolerância à demanda por utilidade e, se não busca o seu próprio fechamento, é assim um gestoprática sempre em constituição, sempre por se constituir.

As FIGURAÇAS de Naves existem não como quem aguarda uma função que ainda não chegou. Ao acusar o capital, me parece, realiza tal gesto justamente na indeterminação que lhe é imanente: não querer ser nada além daquilo que agora, neste momento, figura seu corpo. Corpo provisório, mutante, em fazimento. Há nesse aspecto - o de estar sempre por se constituir - outra consistência trágica nascida do embate com a aparência. É a filosofia trágica de Friedrich Nietzsche que afirma, por meio de uma dialética positiva, que a potência do dionisíaco - e de sua embriaguez como catapulta às desmedidas humanas - reside justamente na busca por um prazer mais elevado que se anuncia no ato do aniquilamento do mundo visível da aparência. De acordo com Roberto Machado, em Nietzsche e a verdade: 
A experiência dionisíaca, em vez de individuação, assinala justamente uma ruptura com o principium individuationis e uma total reconciliação do homem com a natureza e os outros homens, uma harmonia universal e um sentimento místico de unidade; em vez de autoconsciência significa uma desintegração do eu, que é superficial, e uma emoção que abole a subjetividade até o total esquecimento de si; em vez de medida é a eclosão da hybris, da desmesura da natureza considerada como verdade (...) em vez de delimitação, calma, tranquilidade, serenidade, é um comportamento marcado por um êxtase, por um enfeitiçamento, por uma extravagância de frenesi sexual que destrói a família, por uma bestialidade natural constituída de volúpia e crueldade, de força grotesca e brutal. (MACHADO, 1999, p. 21-22)

O eu é, hoje, mais virtual que encarnado, e a FIGURAÇA sabe disso, pois ao se travestir de multidão não busca encontrar nela quem se é, mas justo se perder de quem foi induzida a se tornar. A torrente da multidão é - tal como a das bacantes? - prenúncio de um nomadismo que te obriga a sair de si, pois se o apolíneo é estar na medida, na origem, o dionisíaco é se desmedir, revelar-se em êxtase. Não se trata de um jogo onde a performer seja refém de processos de dessubjetivação, pelo contrário, ela se faz presente e refém de uma sucessão de processos de subjetivação, tomada pela diferença que reescreve sua aparência - altera e flagela sua imagem classe média mulher fruta branca e suculenta - e modifica seus modos de ser e estar em convívio. É outro tipo de poder - de empoderamento sobre o próprio corpo - que produz novos saberes sobre novas possíveis identidades. Eis um modo de existência que ultrapassa a medida da pólis, ultrapassa inclusive a noção de arte: abre-se a vida como processo, a arte como arte viva, a performance como ação que depõe estados e estratos, mesmo sem pegar em armas.

Seria mesmo o núcleo da nossa subjetividade um vazio preenchido por aparências? Quer se tenha resposta para tal pergunta ou não, importa reconhecer que, sob o capitalismo em seu estágio mais avançado e perverso, interessa que os corpos se desmantelem e possam ser controlados por espelhos ocos e sem profundidade, por telas de todos os tamanhos, por toda a parte. Se essa é a consistência que o capitalismo oferece ao ser humano, é talvez porque só ele tenha os remédios para postergar a cura dos cânceres que ele mesmo produz, pois, "o capitalismo presumivelmente é o primeiro caso de culto não expiatório, mas culpabilizador" (BENJAMIN, 2013, p. 22). Benjamin o sentencia: 
Uma monstruosa consciência de culpa que não sabe como expiar lança mão do culto, não para expiar essa culpa, mas para torna-la universal, para martela-la na consciência e, por fim e acima de tudo, envolver o próprio Deus nessa culpa, para que ele se interesse pela expiação. (BENJAMIN, 2013, p. 22)

Em FIGURAÇA, performa-se para se esquecer de si; esquece-se de si para se lembrar do outro; lembra-se do outro para, enfim, não se esquecer que tudo está em passagem, em processo, em mutação e em movimento: tanto corpo como carne, mulher como homem; tempo, valores e hábitos, identidade tanto como discurso; subjetividade tanto como também todas as formas de governo, saber e poder.

\section{5) Montagem}

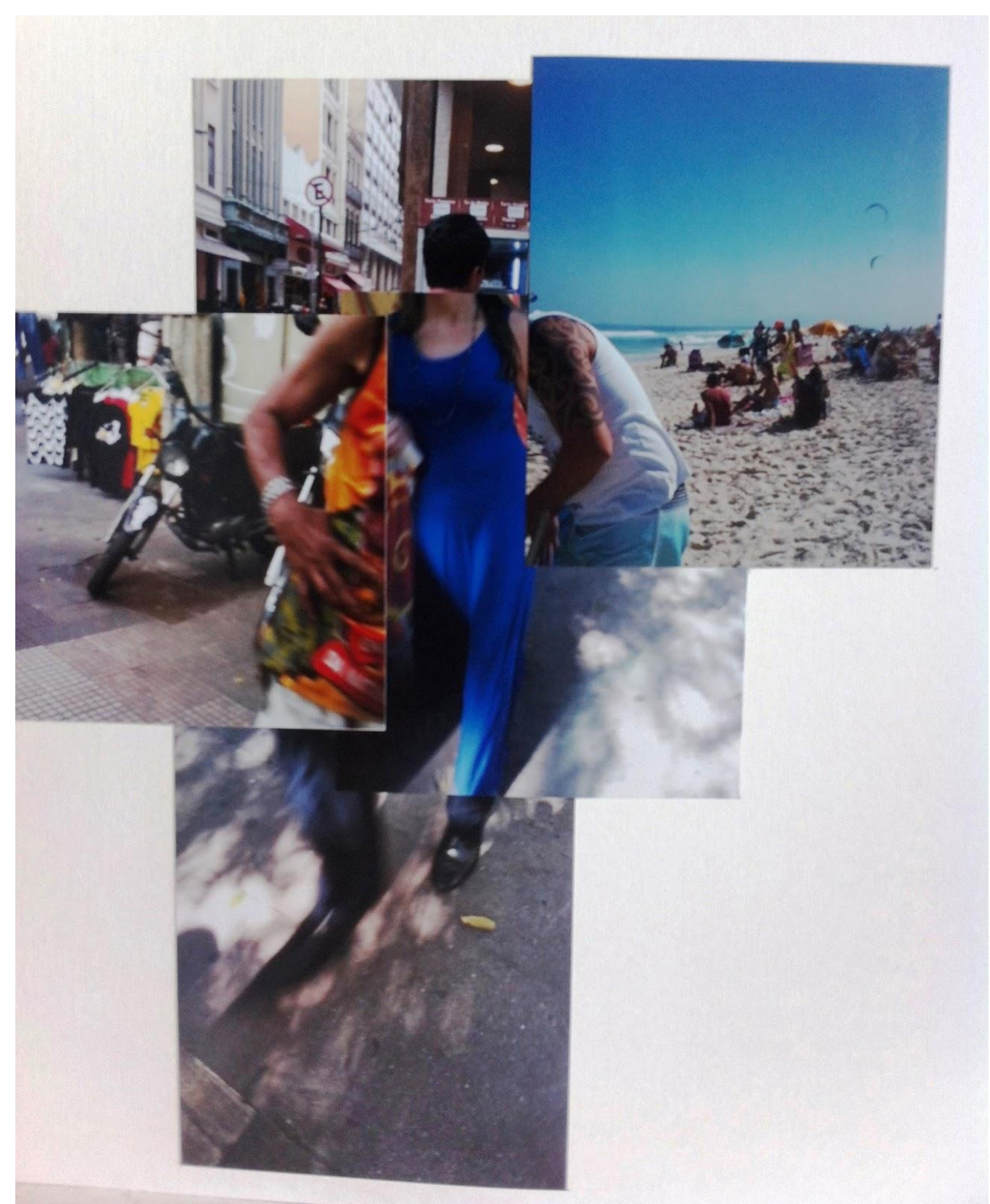

composição FIGURAÇA \#6, Flávia Naves, 2015 


\section{Referências}

AGAMBEN, Giorgio. Profanações. Trad. Selvino J. Assmann. São Paulo: Boitempo, 2007.

BENJAMIN, Walter. O capitalismo como religião. Trad. Nélio Schneider. São Paulo: Boitempo, 2013.

BRANDÃO, Junito de Souza. Teatro grego: tragédia e comédia. Petrópolis, Vozes, 1985.

DELEUZE, Gilles. Conversações (1972-1990). Trad. Peter Pál Pelbart. São Paulo: Ed. 34, 1992.

DELEUZE, Gilles e GUATTARI, Félix. Mil platôs: capitalismo e esquizofrenia 2, vol. 5. Trad. Peter Pál Pelbart e Janice Caiafa. São Paulo: Editora 34, 2012.

DELEUZE, Gilles e GUATTARI, Félix. O Anti-Édipo, Capitalismo e Esquizofrenia 1. Trad. Joana Moraes Varela e Manuel Maria Carrilho. Lisboa: Assírio \& Alvim, 2004.

FÉRAL, Josette. Além dos limites: teoria e prática do teatro. Trad. J. Guinsburg. São Paulo: Perspectiva, 2015.

FOUCAULT, Michel. Microfísica do poder. Trad. Roberto Machado. Rio de Janeiro: Edições Graal, 1979.

FOUCAULT, Michel. Vigiar e punir: nascimento da prisão. Trad. Raquel Ramalhete. Petrópolis, RJ: Vozes, 2014.

GADELHA, Carmem. O trágico e a contemporaneidade. Porto Alegre: VI Reunião Científica da ABRACE, 2011.

KEHL, Maria Rita. O eu é o corpo. In: COCCHIARALE, Fernando \& MATESCO, Viviane (curadoria). Corpo. São Paulo: Itaú Cultural, 2005.

MACHADO, Roberto. Nietzsche e a verdade. São Paulo: Paz e Terra, 1999.

NAVES, Flávia. composição FIGURAÇA \#6. In: FIGURAÇA - travestimento do urbano. Rio de Janeiro: 10 de novembro de 2015. Disponível em: http://performancefiguraca.blogspot.com.br/2015/11/composicao-figuraca-6.html.

Acesso em 14 de mar. de 2018.

NEGRI, Antonio. Cinco lições sobre Império. Rio de Janeiro: DP\&A, 2003.

PELBART, Peter Pál. Elementos para uma cartografia da grupalidade. In: SAADI, Fátima \& GARCIA, Silvana (orgs.). Próximo ato: questões da teatralidade contemporânea. São Paulo: Itaú Cultural, 2008.

ZIZEK, Slavoj. Arriscar o impossível - Conversas com Zizek. Trad. Vera Ribeiro. São Paulo: Martins, 2006. 


\title{
THE TRAGIC IN FIGURAÇA
}

\begin{abstract}
Reflections are presented on the dimension of the tragic in contemporary times based on the performance FIGURAÇA by the Brazilian artist Flávia Naves. The text addresses issues of the body and the feminine, and how the performer, through her practice, relates and problematizes - socially and artistically - her status as a woman. Concepts such as the "crowd" (NEGRI) and "profanation" (AGAMBEN) are drawn on to compose the reflections.
\end{abstract}

\section{Keywords}

Performance. Female. Tragic. Crowd. Profanation. 